\title{
Optimisation of Biomass Waste to Energy Conversion Systems for Rural Grid-Connected Applications
}

\author{
R. Namuli ${ }^{\mathrm{a}, *}$, B. Jaumard ${ }^{\mathrm{b}}$, A. Awasthi ${ }^{\mathrm{c}}$, P. Pillay ${ }^{\mathrm{a}}$ \\ ${ }^{a}$ Department of Electrical and Computer Engineering, Concordia University, 1515 St.Catherine West, S-EV005.139, Montreal, Quebec, Canada H3G 2W1 \\ ${ }^{b}$ Department of Computer Science and Software Engineering , Concordia University, Montreal, Quebec, Canada \\ ${ }^{c}$ Concordia Institute of Information Systems Engineering, Concordia University, Montreal, Quebec, Canada
}

\begin{abstract}
Several rural farms have installed anaerobic digestion systems as manure management systems. Such systems are also used to provide electricity and heating. In these systems, biogas is generated from anaerobic digestion of biomass waste and combusted in a boiler and an engine-generator set, to produce heat and electricity respectively. This paper calculates the size and mode of operation of a biomass waste to energy conversion system that would result in maximum revenue for a given herd size. A Tabu Search optimisation technique is used. A number of equally good solutions are generated. These solutions are plotted on a Pareto front and the best solution is defined as one that lies on this Pareto front. Optimisation of a biomass waste to energy conversion system reduces reliance on electricity from the grid. It also reduces reliance on the use of propane or other fossil fuels for heating.
\end{abstract}

Keywords: biomass waste, energy conversion, Tabu Search, optimisation

\section{Introduction}

Several rural farms around the world have installed anaerobic digestion systems as manure management systems. Such systems are also used to generate electricity and heat. Problems faced with existing systems stem from poor sizing and operation of the biomass waste to energy conversion systems. The objective of the optimisation being carried out is to determine the maximum revenue that can be obtained from these systems, for a given herd size. Revenue is maximised by optimal sizing and operation of the system. This minimises production of excess biogas and also reduces capital costs and the payback period. Maximisation of revenue from such a system will be a result of savings from avoided usage of grid electricity, revenue from selling electricity to the grid and savings from reduced heating costs.

The work is motivated from farms that have faced the problems in the implementation of these systems. Clover Hill Dairy had to upgrade to a $300 \mathrm{~kW}$ engine-generator set because of production of excess biogas [1]. Green Valley Dairy [1], Lamb Farms [2], Sunnyside Farms [3] and Swiss Valley Farms [4] flared excess biogas generated. A.A. Dairy farm installed a biomass waste to energy conversion system at a cost of USD 363,000 [5]. The system's estimated payback period was 6 years [6]. Sheland Farms spent USD 1,320,968 [7] on their

\footnotetext{
*Corresponding author. Tel.:+1 5145590354; fax:+1 5148482802

Email addresses: r_namuli@encs . concordia.ca (R. Namuli), bjaumard@cse.concordia.ca (B. Jaumard), awasthi@ciise.concordia.ca (A. Awasthi), pillay@encs. concordia.ca (P. Pillay)
}

biomass waste to energy conversion system that had an estimated payback period of 16 years [8]. The Klaesi Brothers Farm has a biomass waste to energy conversion system that cost CAD 290,000 and had a payback period of 10 years [9].

A Tabu Search technique (see $[10,11]$ ) is used for optimisation. The Tabu Search technique has not been applied before for optimisation of biomass to energy conversion systems. In [12] mixed integer linear programming was used to optimise the utilisation of waste heat from industries. An evolutionary strategy was used to determine the optimal choice of compressor power ratings, effluent mass flow rate and volume of storage tanks in a heat pump system in [13]. In [14] genetic algorithms and sequential quadratic programming were used to optimise a multi-biomass tri-energy supply system. In [15] the energy production process for a biomass based system was optimised using mixed integer linear programming and mixed integer non-linear programming. The Tabu Search technique was chosen for two reasons: (i) the biomass waste to energy conversion system has a very large solution space and (ii) the system is complex and computationally demanding. Variables that impact on the objective function are used, in the optimisation. The solution space has a total of 1,261,656 variables. Although the variables are discrete, the problem cannot be solved by enumeration of potential solutions due to the large number of combinations of variables. In addition, the optimisation problem being solved is a non- linear constrained problem. The system comprises of functions used to determine the electricity and heat generated. The problem is computationally complex and has many local optima. The problem is therefore better suited to a heuristic approach of problem solving [16]. The choice of which heuristic to use was 
between population based heuristics like genetic algorithms, 107 and trajectory based heuristics like Tabu Search. In population 108 based heuristics a whole set of solutions is updated simulta- 109 neously, whereas in trajectory based heuristics single solutions 110 are evaluated and updated [16]. Population based heuristics are 111 more efficient with regard to exploring the whole space [16], 112 however they are computationally expensive. Trajectory based ${ }_{113}$ heuristics are more suited to computationally demanding problems. The Tabu Search technique was chosen in particular because it is good for exploring a discrete search space with a finite set of neighbouring solutions [16]. This is the case for the optimisation problem being solved. The optimisation technique of this paper is an improvement on research work done so far in solving optimisation problems of biomass energy conversion systems. The other sections of this paper give details of the use of the Tabu Search technique. Section 2 of the paper describes the biomass waste to energy conversion system. Section 3 explains the choice of the optimisation technique. The results of the optimisation are given in Section 4, and Section 5 is on conclusions arrived at.

\section{Description of Models of the Biomass Waste to Energy Conversion System}

This section describes the biomass waste to energy conversion system being optimised. A system diagram of the biomass waste to energy conversion system is shown in Figure 1. The system model consists of a digester, a lagoon, an internal combustion engine, an induction generator, a boiler, a propane tank, a heat exchanger and the electricity grid. The source of biomass waste is dairy farm manure. Manure is stored in a lagoon that allows for variation of flow into the digester. Biogas is generated from the anaerobic digestion of the manure in the digester and combusted in an internal combustion engine to generate torque. The torque is applied to an induction generator to produce electricity. Some of the biogas generated is combusted in a boiler to produce heat. The exhaust heat from the internal combustion engine is captured by a heat exchanger. A propane tank is included in the system to provide a backup fuel supply. This is in the event that biogas generated is insufficient to run both the generator and the boiler, to meet the heating demand. The electricity grid connection is included since excess electricity can be sold to the grid or electricity can be obtained from the grid. The digester requires heating, which is obtained from the system. The following is a description of the modeling of the components of the biomass waste to energy ${ }^{139}$ conversion system.

A plug flow digester is used. It is modeled as four continuous stirred tank reactors $[17,18]$. A mass balance analysis is carried out on each of the waste components in the digester. The waste components undergo disintegration, hydrolysis, bacterial death, acidogenesis, acetogenesis or methanogenesis. Disintegration, hydrolysis and bacterial death are each expressed by:

$$
r=k X_{\mathrm{a}} \quad \mathrm{kgCOD} / \mathrm{m}^{3} / \text { day }
$$

where $r$ is the rate of accumulation of particulate substrate, $X_{\mathrm{a}}$ is the concentration of active biomass and $k$ is a first order rate coefficient. $\mathrm{kgCOD} / \mathrm{m}^{3}$ is the chemical component base unit used to model the anaerobic digestion process [17]. COD is the mass of oxygen required to completely oxidise a given organic compound. Acidogenesis, acetogenesis and methanogenesis are each expressed by:

$$
\rho=k_{\mathrm{m}} S X_{\mathrm{a}} I /(K+S) \quad \mathrm{kgCOD} / \mathrm{m}^{3} / \mathrm{day},
$$

where $S$ is the concentration of the substrate, $K$ is the concentration of the substrate giving one-half the maximum rate of substrate utilisation, $\rho$ is the rate of substrate utilisation, $k_{\mathrm{m}}$ is the maximum specific rate of substrate utilisation and $I$ is a modifier that describe the inhibition of the reactions. Equations (1) and (2) are used to formulate the mass balance equations of the anaerobic digestion process as:

$$
\begin{aligned}
& \frac{d S_{\text {liq }}}{d t}=\frac{q_{\text {in }} S_{\text {in }}-q_{\text {out }} S_{\text {liq }}}{V_{\text {liq }}}+\rho v \quad \mathrm{kgCOD} / \mathrm{m}^{3} / \text { day, } \\
& \frac{d S_{\mathrm{gas}}}{d t}=-\frac{q_{\mathrm{gas}} S_{\mathrm{gas}}}{V_{\mathrm{gas}}}+\rho \frac{V_{\mathrm{liq}}}{V_{\mathrm{gas}}} \quad \mathrm{kgCOD} / \mathrm{m}^{3} / \text { day, }
\end{aligned}
$$

where $S_{\text {liq }}$ is the liquid components concentration, $q_{\text {in }}$ is the volume flow rate of manure influent, $S_{\text {in }}$ is the concentration of manure influent, $q_{\text {out }}$ is the volume flow rate of manure effluent, $V_{\text {liq }}$ is the volume of liquid in the digester, $\rho$ is the rate of substrate utilisation, $v$ is the stoichiometric coefficient, $S_{\text {gas }}$ is the biogas components concentration, $q_{\mathrm{gas}}$ is the volume flow rate of biogas in the digester and $V_{\text {gas }}$ is the volume of biogas in the digester. The mass flow rate of biogas is required for determination of energy converted to heat and electricity. This is calculated from the volume flow rate (4) and the density of the biogas. The density of the biogas is calculated from the pressure of the biogas, using the ideal gas law. The pressure of the biogas is the sum of the partial pressures of the biogas components and water vapour in the head space of the digester. The ideal gas law is also used to calculate the partial pressures of the biogas components. The partial pressure of the water vapour is calculated by:

$$
p_{\text {gas, } \mathrm{H}_{2} \mathrm{O}}=0.0313 \exp (17.75(T-298) / T) \quad \text { bar, }
$$

where $p_{\text {gas, } \mathrm{H}_{2} \mathrm{O}}$ is the partial pressure of water vapour and $T$ is the temperature of the biogas. In addition to the mass flow rate of the biogas, the air-fuel ratio and the LHV (Lower Heating Value) of the biogas are required to calculate torque and exhaust heat generated in the internal combustion engine. The air-fuel ratio of biogas is computed by:

$$
A F=4.76\left(2 x_{1}+0.5 x_{3}\right) M_{\text {air }} / M_{\text {biogas }},
$$

where $A F$ is the air-fuel ratio of the biogas, $x_{1}$ and $x_{3}$ are the molar fractions of $\mathrm{CH}_{4}$ and $\mathrm{H}_{2}$ respectively, $M_{\text {air }}$ is the molecular mass of a standard composition of dry air and $M_{\text {biogas }}$ is the 


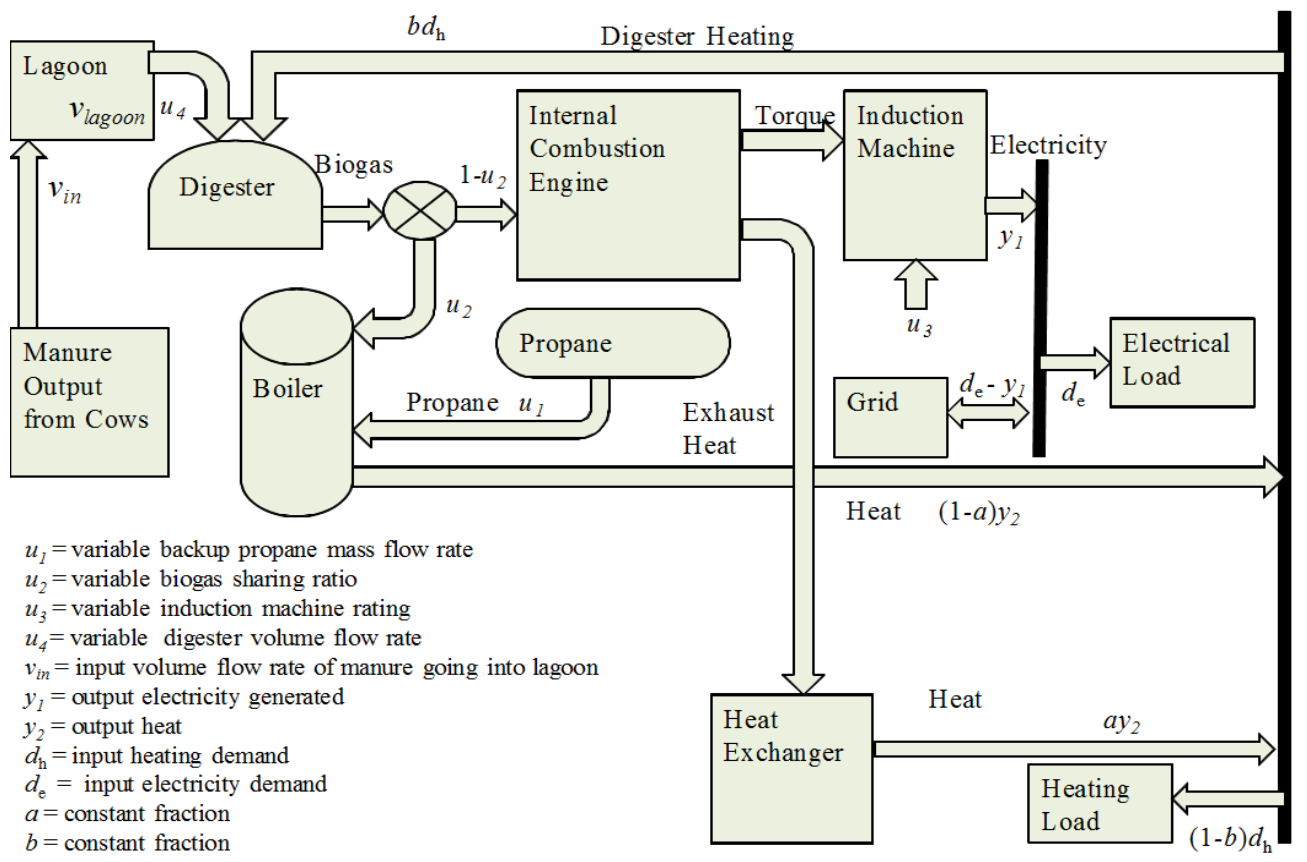

Figure 1: Biomass Waste to Energy Conversion System Model

molecular mass of the biogas. The heat of combustion of the reactants in the digester is used to compute the LHV of biogas as:

$$
L H V_{\text {biogas }}=h r p / M_{\text {biogas }} \quad \mathrm{kJ} / \mathrm{kg} \text {, }
$$

where $L H V_{\text {biogas }}$ is the Lower Heating Value of biogas, hrp is the heat of combustion of the reactants in the digester and $M_{\text {biogas }}$ is the molecular mass of biogas.

The torque generated is applied to an induction generator to produce electricity. The induction generator ratings used in the optimisation are matched with internal combustion engines of similar ratings. The internal combustion engine models are obtained from the ADVISOR software. The John Deere natural gas engine model contained in the ADVISOR software is used to calculate engine power ratings that match the different induction generator ratings. A fuel use map is given in the ADVISOR software. This map gives fuel use at corresponding torque and speed. A user is able to change the torque scale to obtain fuel use for engines of different power ratings. This is because the ADVISOR software specifies the maximum torque at each speed. The user can specify the maximum torque at a required speed in order to match the required induction generator rating. ADVISOR software redefines the torque scale based on the maximum torque specified. The redefined torque scale, the mass flow rate of the biogas, the LHV of the biogas, the air-fuel ratio of the biogas and the engine speed are interpo- ${ }_{18}$ lated to obtain the torque output. The torque output is used in 186 an induction machine model to calculate the electricity output. ${ }_{187}$ The induction machine model is simulated [19] using:

$$
\begin{gathered}
v_{s d}-R_{s} i_{s d}+\omega_{d}\left(L_{s} i_{s q}+L_{m} i_{r q}\right)-L_{m} \frac{d i_{r d}}{d t}=L_{s} \frac{d i_{s d}}{d t} \quad \mathrm{~V}, \\
v_{s q}-R_{s} i_{s q}-\omega_{d}\left(L_{s} i_{s d}+L_{m} i_{r d}\right)-L_{m} \frac{d i_{r q}}{d t}=L_{s} \frac{d i_{s q}}{d t} \mathrm{~V}, \\
v_{r d}-R_{r} i_{r d}+\omega_{d A}\left(L_{m} i_{s q}+L_{r} i_{r q}\right)-L_{m} \frac{d i_{s d}}{d t}=L_{r} \frac{d i_{r d}}{d t} \mathrm{~V}, \\
v_{r q}-R_{r} i_{r q}-\omega_{d A}\left(L_{m} i_{s d}-L_{r} i_{r d}\right)-L_{m} \frac{d i_{s q}}{d t}=L_{r} \frac{d i_{r q}}{d t} \mathrm{~V}, \\
P_{m e c h}=v_{s d} i_{s d}+v_{s q} i_{s q} \quad \mathrm{~W},
\end{gathered}
$$

where $v_{s d}, v_{s q}, v_{r d}$ and $v_{r q}$ are $d q$ voltages, $i_{s d}, i_{s q}, i_{r d}$ and $i_{r q}$ are $d q$ currents, $\omega_{d}$ is the instantaneous speed of the $d q$ winding, $\omega_{d A}$ is the instantaneous speed of the $d q$ winding with respect to the rotor axis, $P_{\text {mech }}$ is the output power of the induction machine, $R_{S}$ is the stator winding resistance, $R_{r}$ is the rotor winding resistance, $L_{m}$ is the stator magnetizing reactance, $L_{s}$ is the stator leakage inductance and $L_{r}$ is the rotor leakage inductance.

The exhaust heat captured by the heat exchanger is calculated as:

$$
Q_{\mathrm{HEX}}=\eta_{\mathrm{HEXeff}} m_{\mathrm{exh}} c p_{\mathrm{exh}}\left(T_{\mathrm{exh}}-T_{\text {water }}\right) \quad \mathrm{W},
$$

where $Q_{\mathrm{HEX}}$ is the heat from the heat exchanger, $\eta_{\mathrm{HEX} \text { eff }}$ is the efficiency of the heat exchanger, $m_{\mathrm{exh}}$ is the mass flow rate of the exhaust from the internal combustion engine, $c p_{\text {exh }}$ is the specific heat capacity of the exhaust from the internal combustion engine, $T_{\text {exh }}$ is the temperature of the exhaust from the 
internal combustion engine, $T_{\text {water }}$ is the temperature of water 233 in the heat exchanger.

It is assumed that a dual fuel boiler is used. The heat output ${ }^{234}$ of the boiler is obtained by:

$$
Q_{\text {boiler }}=\left(u_{1} L H V_{\text {propane }}+u_{2} m_{\text {biogas }} L H V_{\text {biogas }}\right) \eta_{\text {boiler }} \mathrm{W},
$$

where $Q_{\text {boiler }}$ is the heat output of the boiler, $u_{1}$ is the vari- ${ }^{237}$ able mass flow rate of backup propane, $L H V_{\text {propane }}$ is the Lower ${ }_{238}$ Heating Value of propane, $u_{2}$ is the variable biogas sharing ra- ${ }_{239}$ tio, $m_{\text {biogas }}$ is the mass flow rate of biogas from the digester, 240 $L H V_{\text {biogas }}$ is the Lower Heating Value of biogas and $\eta_{\text {boiler }}$ is ${ }_{241}$ the efficiency of the boiler.

The total heat output of the biomass waste to energy conversion system, $y_{2}$ is the sum of the boiler's and the heat exchanger's outputs.

A monthly heating demand profile is generated based on the ${ }^{244}$ number of cows. Heating demand on dairy farms comprises of space heating needs of the milking parlour, hot water for cleaning, and the digester's heating requirements. The space heating needs of the milking parlour are estimated using the software HOT2000 from Natural Resources Canada. The software takes into consideration the monthly variation in temperature. Weather data from Binghamton weather station in New York state is used for space heating needs estimation. This is the closest weather station to the sample farm used in the case 245 study. Hot water needs are estimated from studies carried out 246 on milking parlour heating needs of dairy farms [20, 21]. The ${ }_{247}$ digester's heating requirement is modeled based on the heat ${ }_{248}$ losses from the walls, roof and floor of the digester. The heat 249 required to raise the temperature of influent manure to the op- 250 erating temperature of the digester is also included.

The boiler rating is determined from the heat demand by: ${ }_{252}$

$$
b_{\mathrm{r}}=\max \left(d_{\mathrm{h}}\right)-Q_{\mathrm{HEX}}+\delta_{\mathrm{b}} \quad \mathrm{W},
$$

where $b_{\mathrm{r}}$ is the boiler rating, $\max \left(d_{\mathrm{h}}\right)$ is the maximum heat de- ${ }^{25}$ mand, $Q_{\text {HEX }}$ is the heat exchanger output that corresponds to ${ }^{257}$ the maximum heat demand and $\delta_{\mathrm{b}}$ is an allowance for the boiler rating.

Electrical energy demand is obtained from a typical dairy farm in New York State [6].

The modeling of the components of the biomass waste to energy conversion system has been described in this section. The optimisation methodology is described next in Section 3.

\section{Optimisation Technique}

This section describes the formulation of the optimisation problem. The objective function, the optimisation variables, inputs, outputs and parameters are defined. The optimisation strategy is also described.

\subsection{Objective Function}

The objective of the optimisation is to maximise revenue from a biomass waste to energy conversion system for a given herd size. The objective function is expressed as:

$$
z=\min \left(C_{\text {capital }}+C_{\text {propane }}-C_{\text {incentives }}+C_{\text {grid_electricity }}\right),
$$

where $\mathrm{z}$ is the minimal cost, $C_{\text {capital }}$ is the capital cost amortized monthly, $C_{\text {propane }}$ is the monthly cost of backup propane, $C_{\text {incentives }}$ is the value of incentives given monthly for generation of renewable energy and $C_{\text {grid_electricity }}$ is the monthly cost of electricity obtained or sold to the grid.

\subsection{Optimisation Variables, Inputs, Outputs and Parameters}

The four variables selected for use in the optimisation are given in Table 1 and shown in Figure 1.

Table 1: Variables of the Optimisation

\begin{tabular}{ll}
\hline Variable & Range \\
\hline$u_{1}$ backup propane mass flow rate & $0-0.0036 \mathrm{~kg} / \mathrm{s}$ \\
$u_{2}$ biogas sharing ratio & $0-0.99$ \\
$u_{3}$ induction machine rating & $10,20,50,150,200,250 \mathrm{hp}$ \\
$u_{4}$ digester volume flow rate & $0-59 \mathrm{~m}^{3} /$ day \\
\hline
\end{tabular}

The maximum value of backup propane mass flow rate $\left(u_{1}\right)$ is obtained from the propane flow rate that meets the maximum heat demand when the boiler is combusting propane only, and when the system is operating at the maximum digester volume flow rate. This is because heating is required to raise the temperature of influent manure to the operating temperature of the digester. The biogas sharing ratio $\left(u_{2}\right)$ is the ratio of biogas sent to the boiler. In selection of the maximum value of the biogas sharing ratio, it is ensured that biogas is sent to the engine for electricity generation at all times. The ratings of the induction generator $\left(u_{3}\right)$ are based on induction generators currently operational on dairy farms. The maximum value of the digester volume flow rate $\left(u_{4}\right)$ is determined using:

$$
u_{4}^{\max }=v_{\text {in }}\left(n_{\text {days_max }}+n_{\text {lagoon_storage }}\right) / n_{\text {days_max }} \mathrm{m}^{3} / \text { day }
$$

where $u_{4}^{\max }$ is the maximum digester volume flow rate, $v_{\text {in }}$ is the volume flow rate of manure from the cows, $n_{\text {days_max }}$ is the maximum number of days in a month and $n_{\text {lagoon_storage }}$ is the initial lagoon storage capacity in days. The volume flow rate of manure from the cows is determined from [22].

The inputs and outputs of the system model are given in Table 2 and shown in Figure 1.

The parameters of the optimisation are given in Table 3 . 
Table 2: Inputs and Outputs of the Optimisation

\begin{tabular}{ll}
\hline Input/Output & Description \\
\hline$d_{\mathrm{h}}$ & input heating demand $(\mathrm{kW})$ \\
$d_{\mathrm{e}}$ & input electricity demand $(\mathrm{kW})$ \\
$v_{\mathrm{in}}$ & input volume flow rate of manure $\left(\mathrm{m}^{3} /\right.$ day $)$ \\
$y_{1}$ & output electricity generated $(\mathrm{kW})$ \\
$y_{2}$ & output heat generated $(\mathrm{kW})$ \\
$b_{\mathrm{r}}$ & output boiler rating $(\mathrm{kW})$ \\
\hline
\end{tabular}

Table 3: Parameters of the Optimisation

\begin{tabular}{|c|c|c|}
\hline Parameter & Description & Value \\
\hline$n_{\text {days_max }}$ & maximum days in a month & 31 days \\
\hline$n_{\text {lagoon_storage }}$ & initial lagoon storage capacity & 35 days \\
\hline$n_{\text {max_stop }}$ & $\begin{array}{l}\text { number of iterations for stopping } \\
\text { condition }\end{array}$ & 150 iterations \\
\hline$\delta_{\mathrm{b}}$ & boiler rating allowance & $10 \mathrm{~kW}$ \\
\hline$\delta_{\mathrm{h}}$ & heating demand allowance & $15 \mathrm{~kW}$ \\
\hline$C_{\text {cap_in }}$ & capacity incentive & $1000 \$ / \mathrm{kW}^{1}$ \\
\hline $\max \left(C_{\text {cap_in }}\right)$ & $\begin{array}{l}\text { maximum capacity } \\
\text { incentive }\end{array}$ & $\begin{array}{l}\$ 850000 \text { or } \\
50 \% \text { of } \\
\text { engine cost }\end{array}$ \\
\hline$x_{\text {inc }}$ & performance incentive & $0.07 \$ / \mathrm{kWh}^{1}$ \\
\hline$x_{\mathrm{anc}}$ & factor for ancillary works & 1.15 \\
\hline$p$ & $\begin{array}{l}\text { number of payments } \\
\text { of capital cost }\end{array}$ & 240 \\
\hline$r$ & interest rate & $12 \%$ \\
\hline$c_{\text {lagoon }}$ & unit cost of unlined lagoon & $2.47 \$ / \mathrm{m}^{3} 2$ \\
\hline$c_{\text {propane }}$ & unit cost of propane & $1.98 \$ / \mathrm{m}^{3} 3$ \\
\hline
\end{tabular}

\subsection{Computation of Costs of the Objective Function}

This section describes the calculation of the cost components of the objective function.

The capital expenditure includes building of a digester and lagoon and purchase of a boiler and engine-generator set. Estimation of the cost of building a digester and purchase of an engine-generator set is based on a literature review $[26,27,28,29]$ and is given in Table 4 and 5. Estimation of the cost of the boiler is based on a literature review [30] and is given in Table 6 . The total capital expenditure on the biomass waste to energy conversion system is expressed as:

$$
C_{\text {cost }}=\left(d_{\text {cost }}+g_{\text {cost }}+l g_{\text {cost }}+b_{\text {cost }}-C_{\text {cap in }}\right) x_{\mathrm{anc}}
$$

where $C_{\text {cost }}$ is the total capital expenditure, $d_{\text {cost }}$ is the cost of 304 the digester, $g_{\text {cost }}$ is the cost of the engine generator set, $l g_{\text {cost }} 305$ is the cost of the lagoon, $b_{\text {cost }}$ is the cost of the boiler, $C_{\text {cap_in }}$ is 306 the capacity incentive and $x_{\text {anc }}$ is a factor for ancillary works. $\quad 307$ The total capital expenditure is amortized monthly by:

$$
C_{\text {capital }}=r C_{\text {cost }} /\left(1-(1 /(1+r))^{p}\right) \quad \$,
$$

where $C_{\text {capital }}$ is the capital cost amortized monthly, $r$ is the ${ }^{31}$ annual interest rate, $C_{\text {cost }}$ is the capital expenditure and $p$ is the number of payments.

The cost of electricity from the grid is computed based on the electricity tariff [31] and electricity demand [6]. The user may$$
10
$$

Table 4: Cost Estimates for Plug Flow Digesters

\begin{tabular}{cc}
\hline Digester Size Range $\left(\mathrm{m}^{3}\right)$ & Cost $(\$)$ \\
\hline $900-1200$ & 95,000 \\
$1200-1500$ & 125,000 \\
$1500-1800$ & 200,000 \\
$1800-2100$ & 290,000
\end{tabular}

Sources: The Minnesota Project 2002, Eastern Research Group, Inc. 2004 \& 2005, Resource Strategies, Inc. 2004.

Table 5: Engine-generator Set Cost Estimates

\begin{tabular}{cc}
\hline Engine-generator Set Rating (hp) & Cost (\$) \\
\hline 10 & 30,000 \\
20 & 40,000 \\
50 & 80,000 \\
150 & 250,000 \\
200 & 300,000 \\
250 & 330,000
\end{tabular}

Sources: The Minnesota Project 2002, Eastern Research Group, Inc. 2004 \& 2005, Resource Strategies, Inc. 2004.
287

288

289

290

291

292

\section{o}

$$
C_{\text {incentives }}=\sum_{h=1}^{n_{\text {hours }}} x_{\text {inc }} y_{1} h \quad \$,
$$

where $C_{\text {incentives }}$ is the monthly cost of incentives, $h$ is hours, $n_{\text {hours }}$ is the number of hours for which the system generates electricity, $x_{\mathrm{inc}}$ is the performance incentive and $y_{1}$ is the power output.

Another cost component of the objective function is the monthly cost of propane, obtained from the unit cost of propane [25].

\subsection{Optimisation Strategy}

This section describes the optimisation strategy used. The Tabu list, the neighbourhood, the termination criterion and the constraints are described. The use of pareto solutions to evaluate the objective function is also described.

Four variables are selected for use in solving the optimisation problem. Three of the variables i.e. the backup propane vary monthly, for a fixed induction machine rating (variable mass flow rate $\left(u_{1}\right)$, the biogas sharing ratio $\left(u_{2}\right)$ and the digester volume flow rate $\left(u_{4}\right)$ vary on a monthly basis. The fourth variable the induction machine rating $\left(u_{3}\right)$ is fixed for all the months of the year. In order to simplify the optimisation problem, the Tabu Search is run with the three variables that

$$
\vec{z}=\left[C_{\text {propane }}, C_{\text {grid_electricity }}\right],
$$




\begin{tabular}{cc}
\multicolumn{2}{c}{ Table 6: Boiler Cost Estimates } \\
\hline Boiler Rating Range $(\mathbf{k W})$ & Cost $\mathbf{( \$ )}$ \\
\hline $53.62-97.57$ & 3325 \\
$97.57-118.08$ & 3405 \\
$118.08-150.60$ & 4855 \\
$150.60-182.83$ & 5310 \\
$182.83-212.13$ & 5815 \\
\hline \multicolumn{2}{c}{ Source: Pumps and Pressure, 2011.}
\end{tabular}

where $\vec{z}$ is a cost vector, $C_{\text {propane }}$ is the monthly cost of propane and $C_{\text {grid_electricity }}$ is the monthly cost of grid electricity. Once the minimum cost is obtained from (21) for the different induction machine ratings (variable $u_{3}$ ), the objective function (16) is evaluated to determine the maximum revenue.

The Tabu Search is implemented by sampling each of the three variables $\left(u_{1}, u_{2}\right.$ and $\left.u_{4}\right)$ for a given neighbourhood. The month for which the optimisation is to be carried out is selected based on the optimisation strategy. The neighbourhood of the variable is defined as:

$$
\mathcal{N}(u)^{\text {new }}=\left\{\begin{aligned}
v: v & =u_{i}^{m}+\delta_{i} & & i=1,2,4 \\
v & =u_{i}^{m}-\delta_{i} & & m=1,2,3, \ldots .12
\end{aligned}\right\}
$$

$L B_{v} \leq v \leq U B_{v}: v \in \mathcal{N}(u)$.

where $\mathcal{N}(u)$ is the neighbourhood of the variable $u_{i}^{m}, L B_{v}$ is the lower bound of the neighbourhood and $U B_{v}$ is the upper bound of the neighbourhood. The move from $u_{i}^{m}$ to $u_{i}^{m} \pm \delta_{i}$ is selected within specific limits and step sizes. These step sizes and limits are defined in Section 1.

A Tabu list is formulated from moves that result in the current solution. Each entry of the Tabu list is a vector of the move and its associated month. Reverse moves are also included in the Tabu list. The Tabu list includes a random number selected within a given interval, that decides for how many iterations a Tabu condition persists.

The Tabu Search algorithm is terminated if no improvement ${ }_{37}$ of the incumbent solution has been observed after $n_{\text {max_stop }}$ it- ${ }_{379}$ erations.

There are six sets of constraints for this optimisation problem which are defined as:

$$
\begin{array}{r}
\left(1-u_{2}\right) m_{\text {biogas }} \leq m_{\text {biogas }}^{\mathrm{I}}, \\
d_{\mathrm{h}} \leq y_{2} \leq\left(d_{\mathrm{h}}+\delta_{\mathrm{h}}\right), \\
\left(v_{\mathrm{in}}^{m} d^{m}+V_{\text {lagoon }}^{m-1}-u_{4}^{m} d^{m}\right) \geq 0 \quad \text { for } m=1,2,3, \ldots 12, \\
V_{\text {lagoon }}^{m} \leq v_{\mathrm{in}} V_{\text {capacity_lagoon }} \text { for } m=1,2,3, \ldots 12, \\
\text { HRT } u_{4}^{m} \leq V_{\mathrm{D}} \text { for } m=1,2,3, \ldots 12, \\
b_{\mathrm{r}}=\max \left(d_{\mathrm{h}}\right)-Q_{\mathrm{HEX}}+\delta_{\mathrm{b}},
\end{array}
$$

357 358

\section{f}

For the $150 \mathrm{hp}$ engine-generator set, there are discrepancies in the months of February and December. The month of February has a low power output because the lagoon is building up manure storage for power production during the high demand months of March, April and May. The Tabu Search algorithm maximises revenue and thus avoids solutions that would lead to electricity production that does not meet the demand, hence the build up of manure storage. Manure storage is also being built up for use in the months of June, July and August when tariffs are high. The month of December has a low power output because manure is being stored in the lagoon for use in January. Since the electricity tariff for December and January 


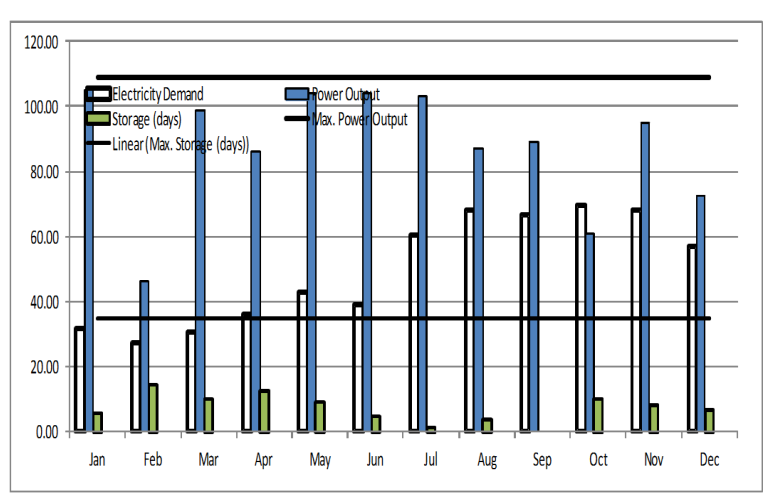

Figure 2: Power Output Profile for 150hp Engine-Generator Set

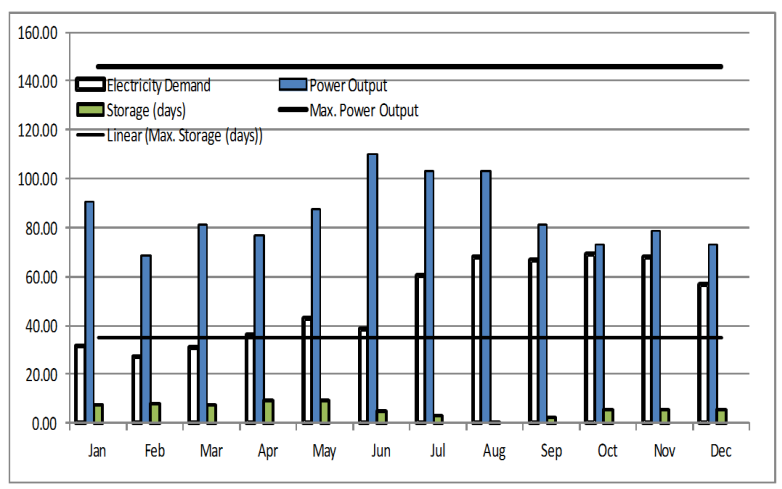

Figure 3: Power Output Profile for 200hp Engine-Generator Set

is the same, the result is acceptable because the manure is used to generate electricity in January when it is sold to the utility company at a high tariff.

The 200hp engine-generator system has high electricity generation in January, June, July and August in line with the high electricity tariffs for these months. The months of February and December have lower than expected electricity production for this engine-generator set. This is because manure is being built up in the lagoon to generate electricity in January, June, July and August.

The electricity generation profile for the $250 \mathrm{hp}$ enginegenerator set is shown in Figure 4. Of all the engine-generator set systems, the $250 \mathrm{hp}$ system gives the highest revenues from the renewable energy incentives and sale of electricity as shown in Table 7. The $200 \mathrm{hp}$ system gives a revenue of $\$ 68654$ and the 250hp system gives a revenue of $\$ 72978$, whereas the $150 \mathrm{hp}$ engine-generator set system gives a revenue of $\$ 70457$. The high revenue of the 250hp engine-generator system is offset by its high capital cost. The highest net revenue is ob- ${ }_{440}$ tained from the $150 \mathrm{hp}$ engine-generator system. Electricity ${ }_{441}$ generation is not maximised for the $200 \mathrm{hp}$ and $250 \mathrm{hp}$ engine- 442 generator systems. This is due to an insufficient supply of 443 biogas. Figure 3 for the 200hp system shows that the lagoon 444 almost empties in August, and has very little manure left in 445 July and September, yet maximum electricity generation is not 446 achieved for any of the months. This applies to the 250hp sys- ${ }_{447}$ tem as well. Figure 4 for the $250 \mathrm{hp}$ system shows that the 448

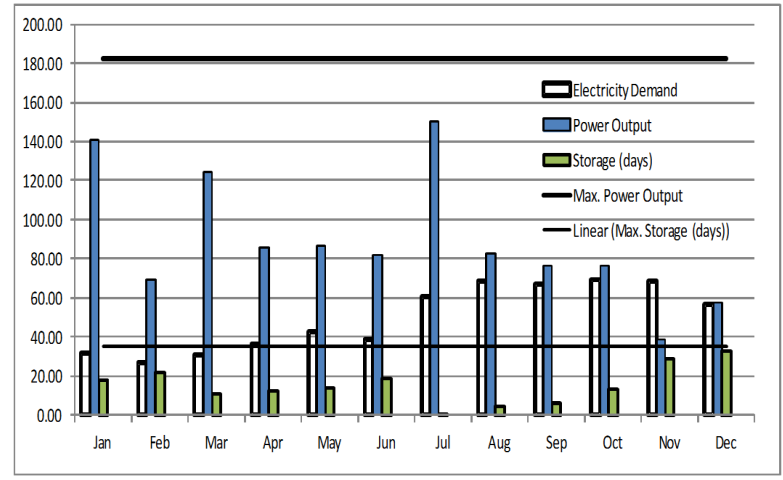

Figure 4: Power Output Profile for 250hp Engine-Generator Set

lagoon empties in July, yet maximum electricity generation is not achieved for any of the months. Thus the system with the $150 \mathrm{hp} \mathrm{engine} \mathrm{generator} \mathrm{set} \mathrm{is} \mathrm{the} \mathrm{most} \mathrm{suitable} \mathrm{for} \mathrm{a} \mathrm{farm} \mathrm{with}$ a herd size of 500 dairy cows.

The electricity generation profiles of the $50 \mathrm{hp}$ and $20 \mathrm{hp}$ engine-generator sets are as expected (Figure 5 and 6 respectively). There is almost maximum electricity generation for all the months. These are engine-generator sets of low power rating and therefore electricity production is maximised in order to meet the farm's needs. It is assumed that production begins in September in the first year of use. The lagoon storage size is set to 90 days, hence the build up of manure stored from September of one year to August of the next year. The lagoon will always have a large amount of manure left over at the end of the period, which is taken as September in this case.

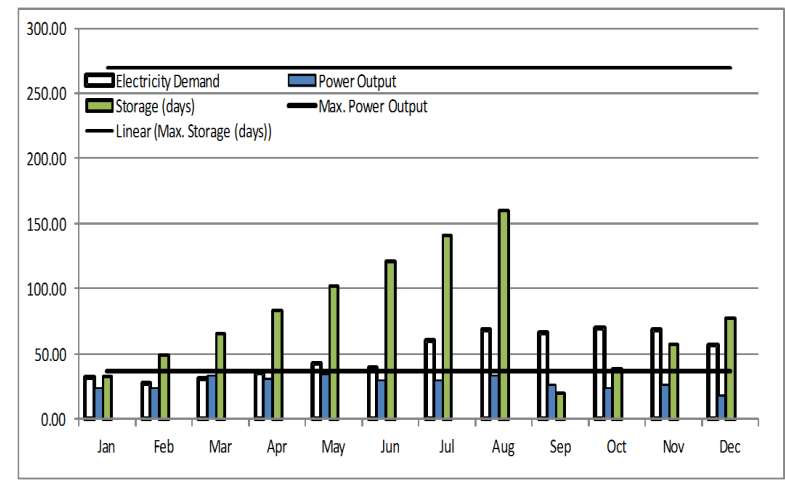

Figure 5: Power Output Profile for 50hp Engine-Generator Set

The 10hp engine-generator set's electricity generation profile (Figure 7) also shows maximisation of power generation throughout the year except for the month of November. This discrepancy is attributed to the parameters used in the Tabu Search optimisation. These are the same parameters as those used for the 20hp engine-generator set system, which has double the power rating. The parameters of the Tabu Search optimisation require further tuning for the 10hp engine-generator set system. 


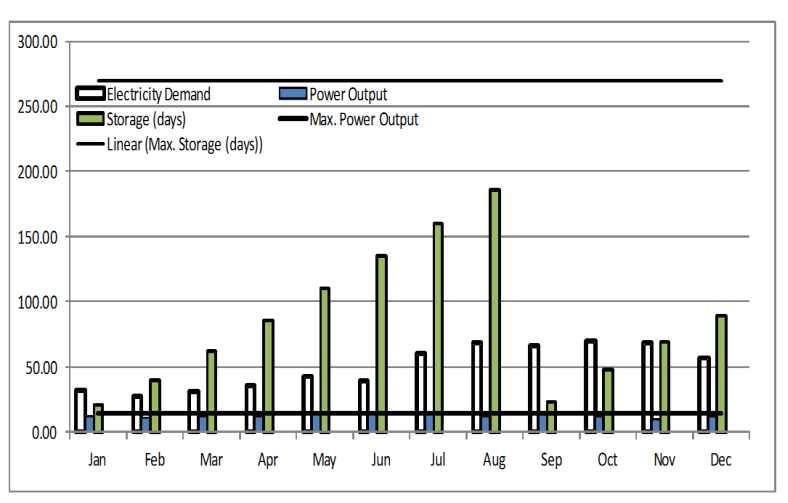

Figure 6: Power Output Profile for 20hp Engine-Generator Set

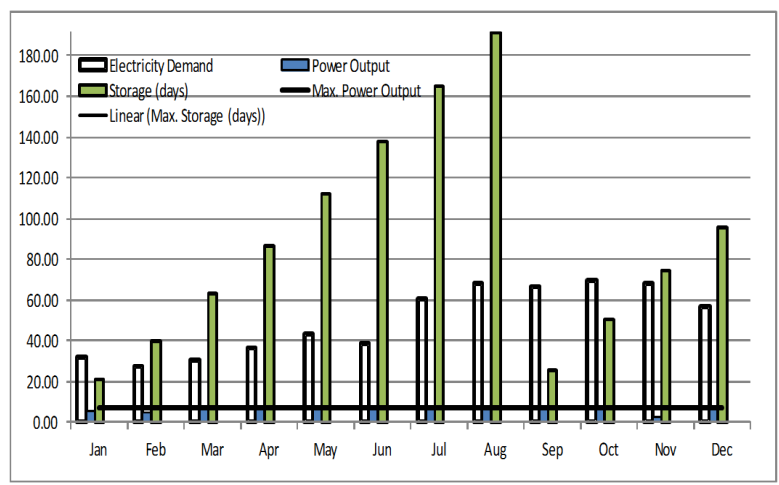

Figure 7: Power Output Profile for 10hp Engine-Generator Set

The heat production profile vs. heat demand profile for the 150hp engine-generator set system is shown in Figure 8. The profile shows that heating demand is met at all times. This applies to all the engine-generator systems.

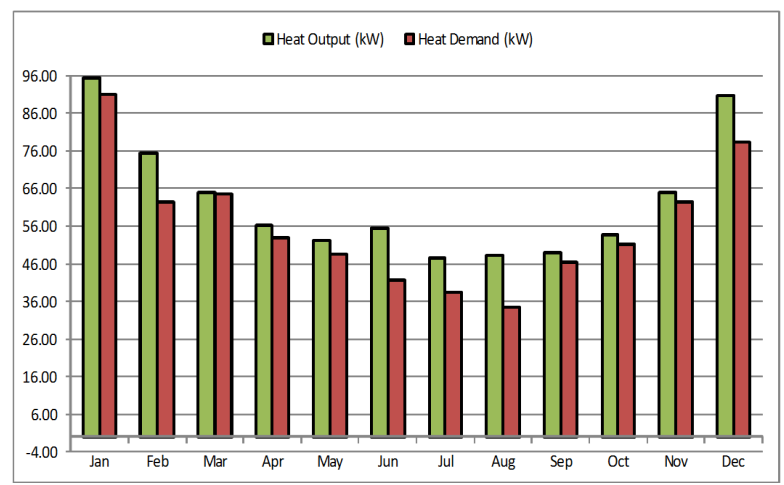

Figure 8: Heat Output Profile and Cost of Propane for 150hp Engine-Generator Set

\subsection{Evaluation of Maximum Revenue}

The maximum revenue that can be obtained from a biomass ${ }_{483}$ waste to energy conversion system on the sample farm with a 484 herd size of 500 dairy cows is evaluated using the objective 485 function (16). Table 7 summarises the revenue from the different engine-generator set ratings.

\begin{tabular}{cccccc}
\multicolumn{6}{c}{ Table 7: Summary of Costs for Different Engine-Generator Set Ratings } \\
\hline $\begin{array}{c}\text { Eng.- } \\
\text { Gen. }\end{array}$ & $\begin{array}{c}\text { Cost of } \\
\text { Capital }\end{array}$ & $\begin{array}{c}\text { Cost of } \\
\text { Pro- } \\
\text { Set }\end{array}$ & $\begin{array}{c}\text { Cost of } \\
\text { Incen- } \\
\text { tives }\end{array}$ & $\begin{array}{c}\text { Cost of } \\
\text { Grid } \\
\text { Elec. }\end{array}$ & $\begin{array}{c}\text { Total } \\
\text { Cost }\end{array}$ \\
Rating & $\mathbf{( \$ )}$ & $\mathbf{( \$ )}$ & $\mathbf{( \$ )}$ & $\mathbf{( \$ )}$ & $\mathbf{( \$ )}$ \\
\hline $10 \mathrm{hp}$ & 21436 & 0 & -3668 & 19301 & 37069 \\
$20 \mathrm{hp}$ & 21821 & 2 & -7529 & 16537 & 30831 \\
$50 \mathrm{hp}$ & 24499 & 7 & -17086 & 9847 & 17267 \\
$150 \mathrm{hp}$ & 36526 & 49 & -53967 & -16490 & -33882 \\
$200 \mathrm{hp}$ & 38455 & 0 & -52570 & -16084 & -30199 \\
$250 \mathrm{hp}$ & 40613 & 62 & -54999 & -17979 & -32303 \\
\hline
\end{tabular}

The 50hp, 20hp and 10hp engine-generator sets not only do not meet the electricity demand of the farm, but are unable to use all the manure generated. This results in the need to buy electricity from the utility company. For example, it is estimated that the farm will spend $\$ 9847$ per annum on electricity (Table 7), with the 50hp engine-generator set system. The farm will however earn $\$ 17086$ from renewable energy generation incentives. The capital costs of the system have to be factored in (Table 7), resulting in a net negative revenue of $\$ 17267$ per annum. This analysis applies to the 20hp and 10hp engine-generator systems. Systems with engine-generator sets of 50hp, 20hp and $10 \mathrm{hp}$ ratings are therefore not economically viable for a farm of herd size 500 .

From Table 7 the solution with the $150 \mathrm{hp}$ engine-generator set gives the maximum revenue for a herd size of 500. The sizing of the components of the $150 \mathrm{hp}$ engine-generator set system is a digester of capacity $1350 \mathrm{~m}^{3}$, a lagoon of 40 days storage capacity and a boiler rated at $133 \mathrm{~kW}$. The proposed digester volume flow rate and biogas volume flow rate to the engine-generator set are shown in Figures 9 and 10 respectively.

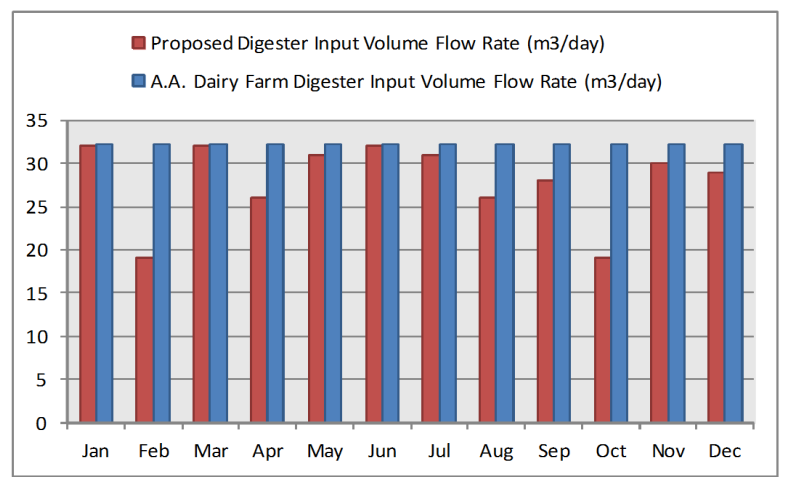

Figure 9: Digester Volume Flow Rate

The sample farm approximated its digester volume flow rate to 85,000 gallons per day [31], which translates to $32 \mathrm{~m}^{3} /$ day for 500 cows in contrast to the value used of $28 \mathrm{~m}^{3} /$ day for 500 cows [22]. This explains the higher digester volume flow rate for the sample farm (Figure 9). 


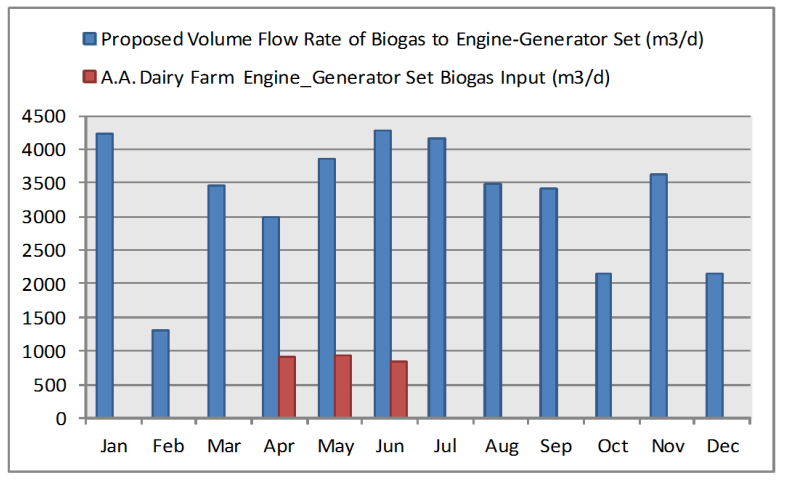

Figure 10: Volume Flow Rate of Biogas to Engine-Generator Set

The cost of propane from the proposed system is shown in Table 7. The minimal cost of propane is explained by the fact that heat is supplied from combusting biogas in the boiler and from exhaust heat captured by the heat exchanger. The Tabu Search optimisation therefore minimises the cost of propane.

Data for the volume flow rate of biogas to the enginegenerator set on the sample farm was only available for three months of the year hence the missing data in Figure 10. The data available shows that a lower volume of biogas is sent to the engine-generator set, despite the farm's engine generator set having a higher rating than the proposed engine-generator set. This is also reflected in the lower electricity production in April, May and June (Figure 11), on the sample farm.

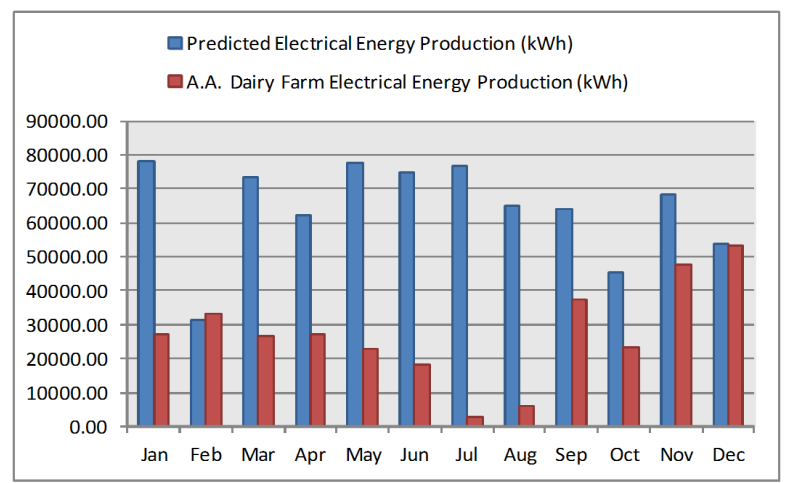

Figure 11: Electrical Energy Production

The installed energy generation capacity of the sample farm 52 is $175 \mathrm{hp}$. It is more than what is required to generate maximum 526 revenue from a system with a herd size of 500. This capacity ${ }_{527}$ is not being fully utilised. This is reflected in the net savings ${ }_{528}$ shown in Figure 13. The sample farm saves $\$ 25815$ per annum ${ }_{529}$ and the Tabu Search optimisation predicts a maximum revenue 530 of $\$ 38133$ per annum from the sale of electricity and avoidance 531 of usage of grid electricity. The sample farm is saving much ${ }_{532}$ less money than what is predicted for a $150 \mathrm{hp}$ engine-generator ${ }_{533}$ set system. Based on the analysis of the Tabu Search optimi- ${ }^{534}$ sation carried out, better utilisation of the installed generation 535 capacity will lead to $48 \%$ more cost savings for the sample 536 farm.

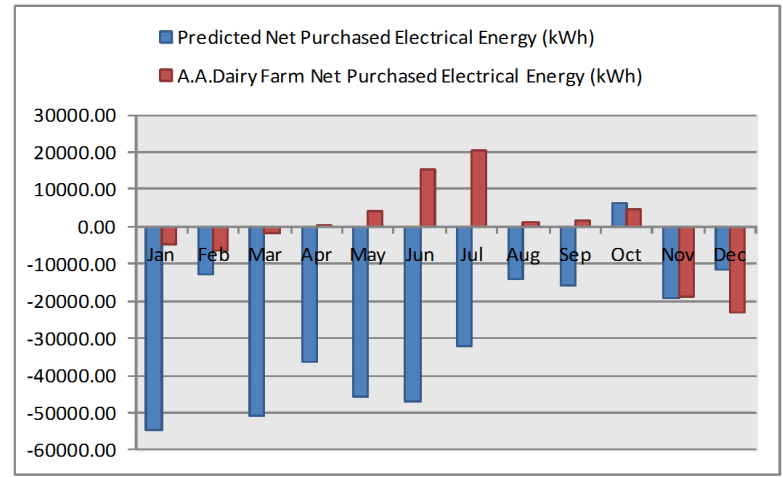

Figure 12: Net Electrical Energy Purchase

- Predicted Net Savings from Usage and Sale of Electricity Generated (\$)

口A.A. Dairy Farm Net Savings from Usage and Sale of Electricity Generated (\$)

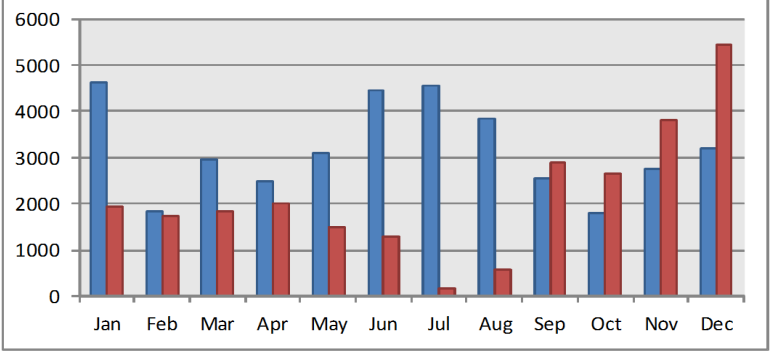

Figure 13: Net Savings from Usage and Sale of Electrical Energy Produced the sample farm. The monthly cost of a backup propane supply was also specified. The predicted cost savings were compared to actual data from the sample farm. The farm is under utilising its currently installed system. From the Tabu Search optimisation carried out, better utilisation of the installed generation capacity will lead to $48 \%$ more cost savings for the sample farm. In conclusion, the Tabu Search optimisation algorithm developed can be used to predict the maximum revenue that can be generated from a given herd size for a biomass waste to energy conversion system. Further work in this area can be done on modification of the algorithm to specify daily energy generation profiles, daily digester volume flow rates and daily biogas 
volume flow rates.

\section{Acknowledgment}

This project is part of the R\&D program of the NSERC Chair entitled Energy efficiency in electrical machines for small renewable energy production systems established in 60 2009 at Concordia University. The authors acknowledge the support of the Natural Sciences \& Engineering Research Council of Canada and Hydro-Quebec. Dr. Claude Laflamme of Hydro-Quebec Insitut de recherche is thanked for his com- 613 ments.

\section{References}

[1] J. Kramer, "Wisconsin Agricultural Biogas Casebook July 2008 Edition," http://www.focusonenergy.com/files/document_management _system/renewables/biogas08_casestudy.pdf, accessed March 2012

[2] CDH Energy Corp., "Lamb Farms. Biogas-Driven Engine System," http://cdhnrgy1.user.openhosting.com/Fact\%20Sheets/Lamb\%20Farms \%20Fact\%20Sheet.pdf, accessed January 2011.

[3] NYSERDA, "DG/CHP Integrated Data System Sunnyside Farms," http://chp.nyserda.org/facilities/details.cfm?facility=156, accessed March 2012.

[4] CDH Energy Corp., "Swiss Valley Farms. Biogas-Driven Engine System," http://cdhnrgy1.user.openhosting.com/Fact\%20Sheets/Swiss \%20Valley\%20Fact\%20Sheet.pdf, accessed January 2011.

[5] C. Gooch, J. Pronto, "Anaerobic Digestion at AA Dairy: Case Study," http://ww2.bse.vt.edu/green/Documents/Cornell\%20Merged.pdf, 2008, accessed March 2012.

[6] NYSERDA, "DG/CHP Integrated Data System A.A. Dairy," http://chp.nyserda.org/facilities/details.cfm?facility $=33, \quad$ accessed March 2012

[7] New York State Environmental Investment Program, "Capital Project Summary Sheland Farms," 638 http://esd.ny.gov/businessPrograms/Data/EIP/EIPProjects/OrganicsShelandFarms.pdf, accessed March 2012.

[8] NYSERDA, "DG/CHP Integrated Data System Sheland Farms," http://chp.nyserda.org/facilities/details.cfm?facility=69, accessed March 2012.

[9] H.K. House, D. Hilborn, "A Small Scale Anaerobic Digester Operating in Ontario-Klaesi Brothers Farm," http://www.wcasfmra.org/biogas_docs/2010\%20NRAES\%20Paper\%20\%20Klaesi\%20Digester.pdf, accessed March 2012.

[10] F. Glover, "Tabu Search - Part I," ORSA Journal on Computing, vol. 1, pp. 190-206, 1989.

[11] _ _ "Tabu Search - Part II," ORSA Journal on Computing, vol. 2, pp. 4-32, 1990.

[12] S.H. Chae, S.H. Kim, S. Yoon, S. Park, "Optimization of a Waste Heat Utilization Network in an Eco-industrial Park," Applied Energy, vol. 87, pp. 1978-1988, 2010.

[13] R. Murr, H. Thieriot, A. Zoughaib, D. Clodic, "Multi-objective Optimization of a Multi Water-to-Water Heat Pump System Using Evolutionary Algorithm," Applied Energy, vol. 88, pp. 3580-3591, 2011.

[14] A.A. Rentizelas, I.P. Tatsiopoulos, A. Tolis, "An Optimization Model for Multi-biomass Tri-generation Energy Supply," Biomass and Bioenergy, vol. 33, pp. 223-233, 2009

[15] M. Bruglieri, L. Liberti, "Optimal Running and Planning of a Biomassbased Energy Production Process," Energy Policy, vol. 36, pp. 24302438, 2008.

[16] M. Gilli, P. Winker, "A Review of Heuristic Optimization Methods in Econometrics, Swiss Finance Institute Research Paper Series No. 8-12," http://www.cigrjournal.org/index.php/Ejounral/article/viewFile/1288/1144, 2008, accessed September 2011.

[17] IWA Task Group for Mathematical Modelling of Anaerobic Digestion Processes D.J. Batstone, J. Keller, I. Angelidaki, S.V. Kalyuzhnyi,

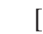
tems as a Method for Making Energy Management Decisions," Ph.D. dissertation, Michigan State University, 1983.

[22] E.M. Barker, H.P. Neumann, "Sizing Dairy Manure Storage Facilities. British Columbia Ministry of Agriculture and Food. Farm Structure Fact Sheet." http://www.agf.gov.bc.ca/resmgmt/publist/300Series/3831002.pdf, 1990, accessed September 2011.

[23] NYSERDA, "Renewable Portfolio Standard Customer-Sited Tier Anaerobic Digester Gas-to-Electricity Program. Program Opportunity Notice (PON) 2138," www.nyserda.org/funding/2138pon.pdf, accessed September 2011.

[24] M.A. Moser, K.F. Roos, "AgSTAR Program: Three Commercial Scale Anaerobic Digesters for Animal Waste, Making a Business from Biomass," in Proceedings of the $3^{\text {rd }}$ Biomass Conference of the Americas, Elsevier Science Inc., Tarrytown, NY., 1997.

[25] U.S. Energy Information Administration, "Weekly Heating Oil and Propane Prices (October-March)," http://www.eia.gov/dnav/pet/pet_pri_wfr_dcus_nus_w.htm, accessed March 2010.

[26] C. Nelson, J. Lamb, "Haubenschild Farms Anaerobic Digester," http://www.mnproject.org/pdf/Haubyrptupdated.pdf, 2002, accessed September 2011.

[27] J.H. Martin, "A Comparison of Dairy Cattle Manure Management With and without Anaerobic Digestion and Biogas Utilization," http://www.epa.gov/agstar/documents/nydairy2003.pdf, 2004, accessed September 2011.

[28] —, "An Evaluation of A Mesophilic, Modified Plug Flow Anaerobic Digester for Dairy Cattle Manure," http://www.epa.gov/agstar/documents/gordondale_report_final.pdf, 2005, accessed September 2011.

[29] J.M. Kramer, "Agricultural Biogas Casebook 2004 Update," http://www.renewwisconsin.org/biogas/AD/Agricultural\%20Biogas\%20 Casebook\%202004\%20Update.pdf, 2004, accessed March 2012.

[30] Hot Water Boiler and Recirculating Pump Selection Chart and Distributor Price, http://www.pumpsandpressure.com/docs/tech/Hot-WaterBoiler-Selection-Guide.pdf, accessed September 2011.

[31] New York State Electric \& Gas Corporation, "New York State Electric \& Gas Corporation Rules, Regulations and General Information,” 2005, Schedule for Electric Service. 